\title{
The Effects of the Degree of Internationalization on Export Performance: A Research on Exporters in Turkey ${ }^{1}$
}

Erkan Özdemir ${ }^{\mathrm{a}}$
M. Hakan Altıntaș ${ }^{b}$

\author{
Serkan Kılıçc
}

\begin{abstract}
The level of internationalization of companies in developing countries is an important factor in the economic success of both businesses and the developing countries. The aim of the present study is to dimension the internationalization of export companies and to determine the effect of these dimensions on the export performance of the companies. The study data were collected from export companies in Turkey with a web-based questionnaire. In the study, structural equation modeling was utilized and in addition to elements in the degree of internationalization (DOI) measurements available in the literature, the speed component was added to the research model. As a result of the research, it was found that the dimensions grouped as sales, country and human factors as the second-order DOI and these dimensions positively affected the export performance of the companies. It was observed that the DOI measurement of the dimensions included in the study supported the results of other studies in the literature and affected the export performance of the companies in developing countries. The study results show that marketing managers should pay special attention to the sub-dimensions such as sales, country and human factors, and the content of the DOI in the internationalization process and in this context should follow export performance.
\end{abstract}

Keywords: Internationalization, Degree of Internationalization (DOI), Export Performance, Exporters, Turkey

JEL Classification: M30, M31, L60

\section{Introduction}

As the borders between the countries have disappeared and competition has been intense worldwide, internationalization of companies has become inevitable. At this point, determining the factors affecting the internationalization rate of companies and knowledge on the effectiveness of the export performance of the companies are important for the companies as well as for the economic achievements of the countries.

The issue of internationalization was particularly addressed by several studies in the context of internationalization models (Fletcher, 2001; Forsgren, 2002; Jansson and Sandberg, 2008; Tuppura et al., 2008; Brennan and Garvey, 2009; Erdil, 2012), the barriers against internationalization (Bauerschmidt et al., 1985; O'Grady and Lane, 1996; Acs et al., 1997; Karagozoglu and Lindell, 1998) and internationalizationperformance relationship (Dean et al., 2000; Contractor, 2007; Pangarkar, 2008; Papadopoulos and Martin,

\footnotetext{
${ }^{a}$ Assoc. Prof., PhD., Uludag University, Faculty of Economics and Administrative Sciences, Department of Business Administration, Bursa, Turkiye, eozdemir@uludag.edu.tr

bProf., PhD., Uludag University, Faculty of Economics and Administrative Sciences, Department of Business Administration, Bursa, Turkiye, mhakan@uludag.edu.tr

cAsst. Prof., PhD., Uludag University, Faculty of Economics and Administrative Sciences, Department of Business Administration, Bursa, Turkiye, skilic@uludag.edu.tr
} 
2010; Carneiro et al., 2011a; Prange and Verdier, 2011; Naik and Reddy, 2013; Singla and George, 2013; Kayabaşı et al., 2010). Degree of Internationalization (DOI) and performance relationship (Tallman and Li, 1996; Lu and Beamish, 2001; 2004; Thomas and Eden, 2004; Ruigrok et al., 2007; Loncan and Nique, 2010) was among the topics that were scrutinized. However, studies on the degree of internationalization of companies in developing countries have been limited. Addressing internationalization, which has a very important role in the socio-economic development of particularly the developing countries (the degree of internationalization and the impact on export performance), would provide considerable contributions to the development of companies in particular, and the national economy in general.

The main assumption of the internationalization process for companies is to capture opportunities for profitability in foreign markets as well as saturation in the domestic markets. When internationalization models are examined, it could be observed that the internationalization process is gradual starting from the domestic market and exports (Cavusgil, 1980). Thus, it could be argued that there exists exploration and exploitation periods between the company's native country and the foreign country (Bandeira-de-Mello et al., 2016). It seems necessary to establish international ties in these two periods as an expression of orientation and participation in foreign markets (Ogasavara et al., 2016). Internationalization of companies, based on the intensity of internationalization, continues within a structure that could be expressed as learning-participation, development of knowledge, and utilizing the opportunities in the market (Welch et al., 2016). While the experience acquired by companies in their domestic market is significant, the prolongation of the time spent in the home market creates a lack of knowledge about foreign markets (Blomstermo et al., 2004; Torlak et al., 2007; Altuntaş et al., 2015).

When internationalization process is considered as a mechanism of resources, it could be observed that the characteristics of company, resources and decision makers should be considered in conjunction based on organizational, entrepreneurial and technological factors (Dhanaraj and Beamish, 2003; Canitez and Yeniçeri, 2007; Sürer and Mutlu, 2012; Altuntaş et al., 2015). Thus, the human factor is an important element of the degree of internationalization (Onkelix et al., 2016). The human factor has a significant impact on the pace of internationalization (Loane et al., 2007) and export performance (Ganotakis and Love, 2012) of companies. On the other hand, selection of country as an export market could be a significant costreducing factor for the relationships of the exports company with the domestic and foreign country (He et al., 2016) Furthermore, country-scale geographical expansion is considered as one of the indicators of the degree of internationalization, in other words the intensity of exports (Perçin, 2005; Boehe and Jiménez, 2016).

Differences and distinctive features of the foreign country are an important factor in the internationalization process of companies (Hitt et al., 2016). Another important factor in international involvement is the intensity of exports (current and relative growth rate of the weight of overseas sales) (Martineau and Pastoriza, 2016). This factor is related to the FSTS dimension of Degree of Internationalization (DOI). In the context of the degree of internationalization, a relationship is established between the weight of international sales and the acceleration of internationalization (Tan and Mathews, 2015).

DOI is also modeled as an important part of the performance element (Chen and Tan, 2012). In the relationship between internationalization and performance, $R \& D$ intensity, country of origin, age, size, and product diversification factors serve as a mediator effect (Bausch and Krist, 2007). When the determinants of export performance are examined, it could be observed that internal-external factors are important determinants. Thus, the corporate characteristics in the internationalization process are included in internal factors.

The main objective of the present study is to determine the dimensions that constitute the degree of internationalization of the export companies based on the sample of Turkey, which is one of the developing countries, and then to reveal the effects of these dimensions on the export performance of the companies. The basic structure of the degree of internationalization in the study was based on the DOI measurement and export performance was analyzed based on three basic factors; human, sales and country. The findings of the present study, based on the sample of a developing country, in addition to contribution to the 
literature, provide a significant contribution to the determination of the dimensions that affect the companies of developing countries and the degrees of the effects of these dimensions. The results of the study establish the precursors of the future policies and strategies that could be developed to facilitate the internationalization processes and improve the performances of the companies in developing countries and provide recommendations for the executive management of these companies.

The rest of the article is structured as follows: Initially, an extensive literature review was conducted on the internationalization process and the relationship between the degree of internationalization and performance. This section is followed by a description of the research methodology and the procedures used in the study. Subsequently, the findings are discussed based on theoretical and managerial implications and recommendations for future research are presented.

\section{Conceptual Framework}

The internationalization process, which is a significant contributor to the economic growth of the developing countries (Rutashobya and Jaensson, 2004), is conceptualized as the dissemination of the corporate activities outside the national borders (Erkutlu and Yiğit, 2001: 149) and mainly involves export activities as a start (Cavusgil and Nevin, 1981). However, it should go beyond this phase (Jones, 2001) and should adapt the transformation from a conventional structure to dynamic feasibility structure (Knudsen and Matsen, 2002).

Although the continuity of the internationalization process is in interaction with the export stimuli (Sullivan and Bauerschmidt, 1988; Fillis, 2001), factors such as foreign language knowledge, adaptation to foreign market cultures, adaptation to legal systems, financial strength (Acs et al., 1997), communication with foreign customers (Bauerschmidt et al., 1985), and company differentiation (O'Grady and Lane, 1996) play a decisive role in the internationalization process of companies. Especially in the first stage of internationalization, foreign market knowledge plays an important role (Diamantopoulos et al., 1990). One of the most important factors that increase the internationalization performance of companies (Hsu and Pereira, 2008) is market intelligence in the sense of better understanding foreign market actors (Leonidou and Theodoslou, 2004) and learning legal, economic, cultural and market infrastructure (Wood and Robertson, 2000). However, the lack of knowledge on exports could lead to instability and difficulties in the process of entering the foreign markets (Leonidou, 1997; Morgan and Katsikeas, 1998). To overcome this obstacle (Thomas and Arajuo, 1985), foreign market knowledge and experience, which is inversely proportional to domestic market embeddedness (Blomstermo et al. 2004), is also a decisive factor in lowering the risk in the internationalization process (Lee and Chen, 2003) and it even is a determinant factor (Altintaş and Özdemir, 2006).

At the company level, the process of internationalization is affected by the commitment of the management (Solberg et al., 2002; Loane et al., 2007), export management experience (Leonidou, 2000), managerial education level (Wang et al., 2008), quality of exports staff (Pinho and Martins, 2010), domesticglobal corporate focus (Boter and Holmquist, 1996), company networks established with foreign markets (Chetty and Holm, 2000; Rundh, 2001), corporate characteristics (Kling and Weitzel, 2011; Perçin, 2005; Canıtez and Yeniçeri, 2007; Danışman and Sökmen, 2007), dynamics of the company (Andersson et al., 2004). Furthermore, the level of maturity of the industry of the companies (Andersson 2004) is another factor affecting the internationalization process.

The performance and focus of companies in foreign markets (Dean et al., 2000), the increase in international experience and the degree of internationalization (Contractor, 2007; Papadopoulos and Martin, 2010) increase the export performances of the companies. Similarly, the strategic orientation (Carneiro et al., 2011b; Altuntaş et al., 2015; Kurt and Bilge, 2016), the export decision-making process (Naik and Reddy, 2013) and the existing degree of internationalization (Prange and Verdier, 2011) have an impact on the performance of the companies. Thus, it is expected that international expansion would increase the performance of companies (Bolaji and Chris, 2014). Korkmaz et al. (2009) also investigated innovation capabilities of firms and their effects on export performance. In their study, it is found that there are no 
significant differences innovation capabilities of firms in terms of export frequencies, export behaviors (export/sales revenue) and innovation frequencies.

Prior to the beginning of the internationalization process, it is generally expected that companies, except certain industries and companies, would reach a certain level of experience in the national market. Companies could plan internationalization by passing through four stages of awareness, interest, trial and adoption (Lim et al., 1991) and export participation (Wickramasekera and Oczkowski, 2004), utilizing the corporate resources strategically in their exports behavior (Reid, 1983).

In the process of transition to internationalization, foreign market penetration, foreign production presence and country scope play an important role (Thomas and Eden, 2004). Thus, it could be stated that the age (Singla and George, 2013), country (Tallman and Li, 1996; Capar and Kotabe, 2003) and geographical diversity (Lu and Beamish, 2004) of the company have an effect on the relationship between internationalization and performance. However, in certain cases, there exists several factors with a decreasing effect on the performance of internationalization (Pan and Chao, 2010) due to diversities among countries and the difficulties in investment control (Bobillo et al., 2012).

The predecessors of the internationalization process discussed above have features that increase the level of experience in internationalization of the companies. Experience, which has a triggering effect in internationalization (Westhead et al., 2002), could be attributed to greater participation in exports (Lee and Ali, 2001) and development and attitudes of companies on exports (Gripsrud, 1990). Thus, the obtained experience is first transformed to the level of exports and then to the degree of internationalization.

It was observed that different measurements were used in the literature to determine the degree of internationalization. These measurements are Transnationality Index-TNi (UNCTAD, 1998), Transnationally Spread Index-TSi (letto-Gillies, 1998) and Degree of Internationalization Scale-DOI (Sullivan, 1994). In the literature, the most commonly used scale was the DOI. Five elements are the main descriptors of the DOI (Sullivan, 1994) and these are FSTS, FATA, OSTS, TMIE, and PDIO. Over time, FETE was added to these elements and the DOI was scrutinized with 6 elements (De Clerq et al., 2005). However, in the present study, the speed factor (Chetty et al., 2014), which refers to the period between the year of establishment of the company and the year of the initial exports (Moen and Servais, 2002), was used as an additional variable in the measurement of DOI. The speed in question was scrutinized as slow, incremental, time-dependent and experience-accumulative (Luo et al., 2005).

The increase in the DOI level means that companies are progressing in the internationalization process and has an impact on the export performance of the companies (Pangarkar, 2008). When subanalyses of DOI elements are conducted, it would be observed that there is a correlation between the performance and the factors of FSTS (Riahi - Balkaoui, 1998, Nehrt, 1999, Ruigrok et al., 2007; Loncan and Nique, 2010), FATA (Sullivan,1994; Ramaswamy et al., 1996; Nehrt, 1999; Kennelly and Lewis, 2001), PDIO (Conway and Swift, 2000; Evans et al., 2000; Loncan and Nique, 2010), TMIE (Sua'rez-Ortega and A'lamoVera, 2005), FETE (Contractor et al., 2003; Hassel et al., 2003; Chang, 2007; Greve et al., 2009; Nielsen, 2010; Zhang and Toppinen, 2011), OSTS (Sullivan,1994; Ramaswamy et al., 1996; Kennelly and Lewis, 2001). Several correlations such as S (Lu and Beamish, 2004), J and U (Contractor et al., 2003), reverse U (Elango and Sethi, 2007), positive linear, positive decreasing (López-Morales and Gómez-Casas, 2014) between DOI and performance have been established by various researchers.

\section{Methodology}

\subsection{The Aim of the Study}

The aim of the present study is to determine the degree of internationalization of exports companies in Turkey, a developing country, and to show the effect of the degree of internationalization on export performance of exporters. 


\subsection{The Sampling and Method}

The target population of the present study included companies in different industries that conduct exports in Turkey. The study was conducted on export companies registered in thirteen exports associations in the Turkish Exporters Assembly (TIM). The judgment sampling method was used in the study. Initially, it was contacted with exports associations and then obtained e-mail addresses of registered member companies. A web-based questionnaire was developed and used in the study. An e-mail containing links and a request to fill out the online survey form was sent to the members registered in these associations between February 15 and April 15, 2016. However, since the response rate was low and approximately half of the sent e-mails did not reach to the correspondents due to various reasons (email addresses being out of date, emails being sent to spam mail folders in recipient mailboxes), a second e-mail was sent to the responders to remind them the online survey. Questionnaire link was sent to nearly 20.000 member of Turkish Exporters Assembly (TIM) by e-mail. As a result, a total of 460 exports companies completed the online survey form throughout Turkey. The response rate was \% 2.2. However, after examining the responses, it was determined that 50 questionnaires were not suitable for analysis and the remaining 410 questionnaires were included in the analysis.

\subsection{Survey Form and the Scales}

There were two groups of questions in the survey form. The first group included categorical questions about the participant individuals and companies, and the second group included questions that reflected the degree of internationalization and exports performance of the exports companies. The questionnaire, the details of which are provided below, was first translated from English to Turkish, then back-translated to English, to ensure the accurate translation of the questions. To test the face validity and comprehensibility of the questions in the developed questionnaire, a pilot scheme was conducted with 20 volunteering company managers selected with convenience sampling method. As a result of the pilot scheme, small changes were made and the final questionnaire was designed and used to collect the data.

\subsubsection{The Degree of Internationalization (DOI)}

The items of the scale related to the degree of internationalization (DOI) used in the research were designed based on the conducted literature review (Sullivan, 1994; De Clerq et al., 2005). The main dimensions in DOI measurement are calculated as ratios.

DOI dimensions and ratios discussed in the study are presented below:

- FSTS: Foreign sales / Total sales

- FATA: Total foreign assets / Total assets

- OSTS: Number of foreign offices / Total number of offices

- TMIE: Experience of exports managers / Total experience of all managers

- PDIO: Number of countries of export / Total number of countries in the market

- FETE: Number of exports employees / Total employees

- FIRST EXPO (speed of conducting the first foreign sales) = Current year - first year of foreign sales / Years in operation

- COUNTRY (geographical expansion of foreign sales) $=$ Number of countries of export $/$ Years in operation

It was used interval scale that indicates possible rates instead of nominal rates of DOI factors due to the difficulties of obtaining the actual data from the companies. The study scale has five intervals $(1=1-20$ $\% ; 2=21-40 \% ; 3=41-60 \% ; 4=61-80 \% ; 5=81-100 \%$ ) which were analyzed as very low, low, medium, high and very high, respectively. 
In the study, the DOI was considered as a tool used to determine and measure the level of internationalization. It was also used as an element of describing the internationalization of export businesses. As described above DOI was measured subjective, not an objective manner. There are several studies about using of subjective (Vardar, 2016) and non-ratio scales (Cadogan et al., 2001; Gubik and Bartha, 2014) in internationalization of export companies. Also, the speed factor was included in the study as Country and First Expo as an additional dimension in the measurement of the DOI (Chetty et al., 2014).

\subsubsection{Export Performance}

Export performance was calculated as shown below with a 2 item 5-point Likert scale $(1=$ very low, 2 = low, 3 = moderate, 4 = high, 5 = very high) utilizing the related literature (Lages and Lages, 2004; Lages et al., 2005; Diamantopoulos and Siguaw, 2006):

- Export sales volume

- Export profitability

These two dimensions, which are perhaps the two most significant performance measurement variables for many international companies, are addressed as dimensions that demonstrate the objective performance of companies in the internationalization process. Findings and measurements obtained in the present study are discussed below.

\section{Results}

\subsection{Demographic Characteristics}

$82 \%$ of the respondents who participated in the survey were males and $18 \%$ were females. Of the participants, $9 \%$ had up to 5 years of company experience, $15 \%$ between $6-10$ years, $23 \%$ between $11-16$ years, $20 \%$ between $17-22$ years, $15 \%$ between $23-30$ years, $18 \%$ had a company experience of over 31 years.

Findings on the companies that employed the participating respondents demonstrated that $5 \%$ of the export companies were founded between 1950-1970, 17\% between 1971-1990, 58\% between 1991-2010 and $20 \%$ were founded after 2010 . It was found that $7 \%$ of these companies conducted their first foreign sales between 1970-1990, 53\% between 1991-2010 and 40\% after 2010. Employee-based size of the companies can be classified into four groups: Micro businesses; $1-9$ employees (30.24 \%), small businesses; 10-49 employees (37.56 \%), middle-sized businesses; 50-249 employees (23.66 \%) and big-sized businesses; 250 or more employees (8.54\%).

\subsection{Research Model and Hypothesis}

The main purpose of the study is to determine whether the DOI has a positive effect on export performance in second-order perspective. The hypothesis of the study is:

$\mathrm{H}_{1}$ : The DOI has a positive effect on export performance.

The dependent variable was the export performance and the independent variable was the DOI. DOI was classified under eight items, which were scrutinized as endogenous - latent, while export performance was scrutinized as an exogenous - latent variable. Literature on internationalization demonstrates that studies conducted with structural modeling were focused on human capital (Ruzzier et al., 2007), managerial attitudes (Javalgi et al., 2003), participation (Yip et al., 2000; Papadopoulos and Martin, 2010), performance (Hsu and Pereira, 2008), and domestic market experience and knowledge on internationalization (Blomstermo et al., 2004). The reason for preference of the structural equation model is to conduct a classification at the second order of DOI (See figure 1). 
Figure 1. Second-order Model of DOI

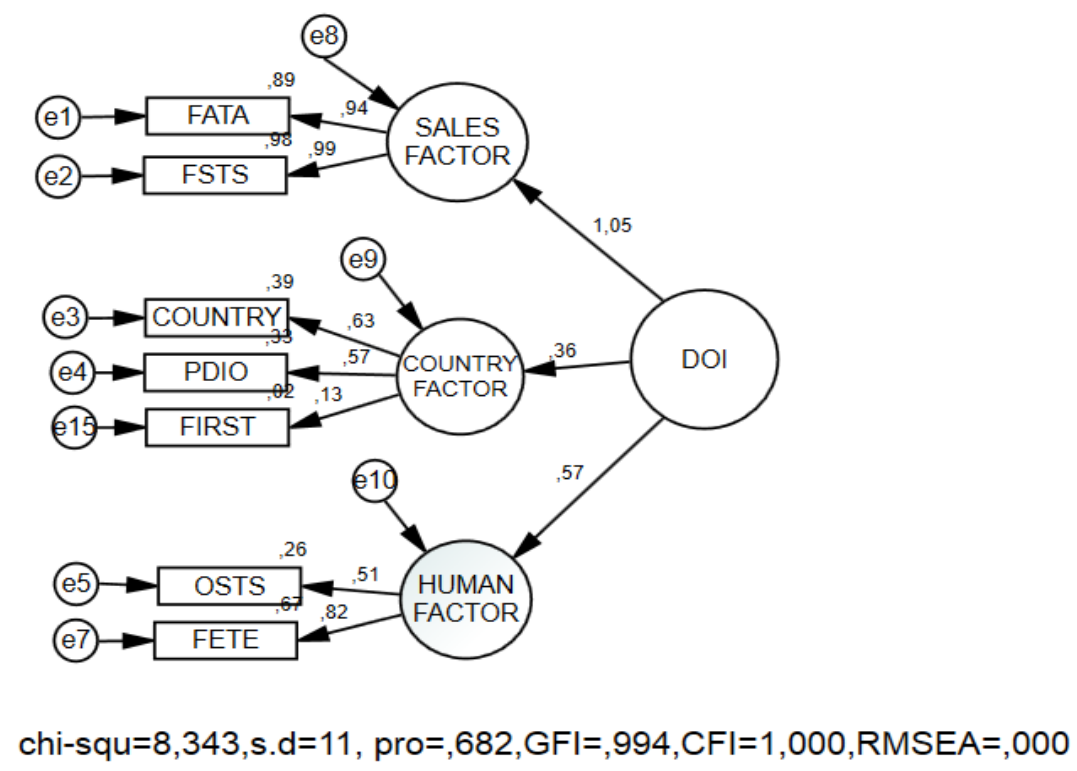

In the present study, DOI dimensions were classified based on their content and examined within three main factors. The PLS-SEM technique was preferred because the main objective of the study was to predict and describe the main target structures (Hair et al., 2011: 144). The first group included the salesasset group, the second included the country expansion group, and the last group was the human resourcesemployee group. The measurement variables demonstrated a reflective structure. The basis of this conceptualization was that sales, country and human resources were significant for the internationalization of a company. At this stage, the validity of the DOI model was tested with DFA in the first-order and the second order. In the literature, several authors stated that CFI values have traditionally been used with RMSEA, which is used in structural models, but alternative studies had to be conducted in certain cases (Yuan et al., 2016: 319-320). The cut-off values of the established indices were used in the current study (Bentler, 1990; Schermelleh-Engel et al., 2003). In fact, it was stated that RMSEA was more effective for a good fit in the confirmatory plane (Rigdon, 1996: 378).

Figure 2. Structural Equation Modeling: DOI to Export Performance

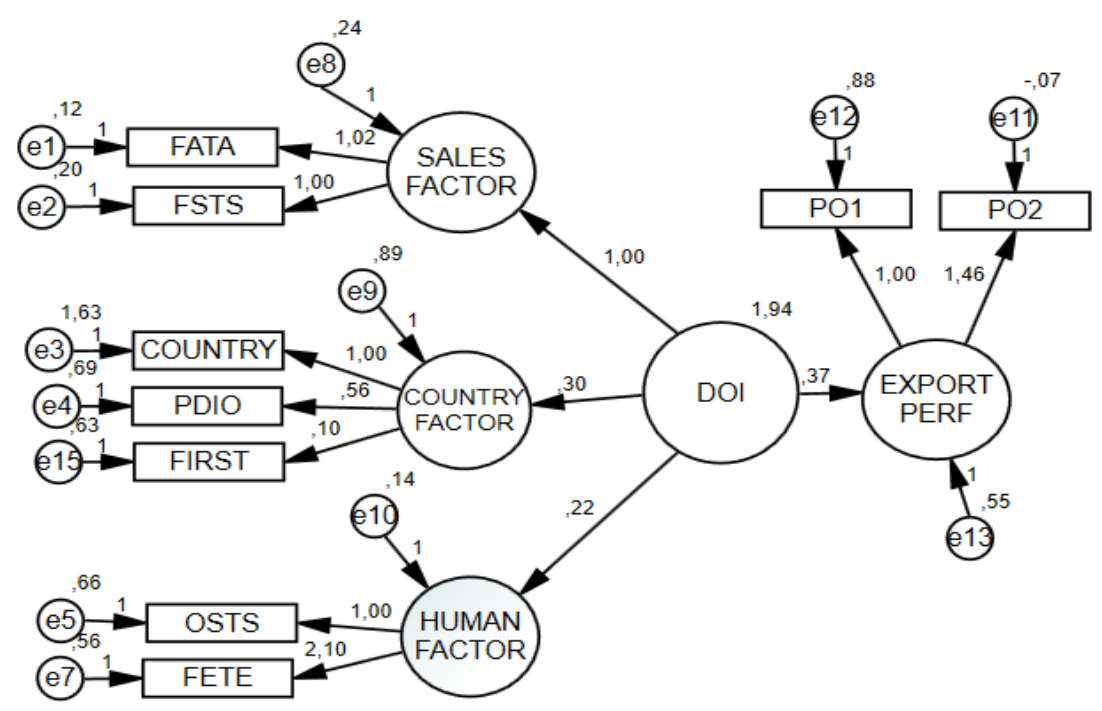

chi-squ $=39,347, \mathrm{~s} . \mathrm{d}=23, \mathrm{pro}=, 018, \mathrm{GFI}=, 980, \mathrm{CFI}=, 989, \mathrm{RMSEA}=, 042$ 
As a result of conducted analyzes, it was observed that the fit indices of these two level analyzes were within acceptable limits in figure 2. Thus, second-order analysis was preferred (CFI $=1.00, \mathrm{GFI}=.993$, RMSEA $=.00$, chi-square $/ \mathrm{df}=.76$, prob $=.682$ ). The TMIE variable was excluded from the analysis because it violated the validity. Although high-level analysis is effective on parameter estimates, in certain cases it could cause col-linearity problems (Bagozzi and $\mathrm{Yi}, 2012$ : 24). Reliabilities of constructs were found in acceptable levels (sales factor: 0.965; country factor: 0.483 and human factor: 0.573). However, when the correlation values between independent variables were examined in table 1 , it was observed that there was no collinearity. Thus, a second-level CFA analysis was preferred. In the choice of the second level, the ratio between first-order and second-order chi-square values was utilized. The $\mathrm{H}_{1}$ hypothesis determined for the study was accepted (Beta $=.37$ ).

Table 1. Correlations between the Variables

\begin{tabular}{|c|c|c|c|c|c|c|c|c|c|c|c|}
\hline & & 1 & 2 & 3 & 4 & 5 & 6 & 7 & 8 & 9 & Mean \\
\hline COUNTRY & 1 & 1 & $0,200^{* *}$ & $0,110^{* *}$ & $0,086^{*}$ & $0,229^{* *}$ & $0,037^{*}$ & $0,363^{*}$ & $0,22^{*}$ & $0,257^{*}$ & 1,108 \\
\hline FATA & 2 & 1 & $0,467^{*}$ & $0,112^{*}$ & $0,933^{* *}$ & $0,295^{* *}$ & $0,207^{* *}$ & $0,363^{*}$ & $0,547^{* *}$ & 2,939 \\
\hline FETE & 3 & & 1 & $0,046^{*}$ & $0,486^{* *}$ & $0,419^{* *}$ & $0,082^{*}$ & $0,168^{*}$ & $0,265^{* *}$ & 1,790 \\
\hline FIRST & 4 & & & 1 & $0,118^{*}$ & $0,015^{* *}$ & $0,040^{*}$ & $-0,021$ & $0,040^{*}$ & 0,649 \\
\hline FSTS & 5 & & & & 1 & $0,305^{*}$ & $0,216^{* *}$ & $0,360^{*}$ & $0,508^{* *}$ & 2,961 \\
\hline OSTS & 6 & & & & & 1 & $0,115^{*}$ & $0,124^{*}$ & $0,201^{* *}$ & 1,352 \\
\hline PDIO & 7 & & & & & & 1 & $0,107^{*}$ & $0,161^{* *}$ & 1,982 \\
\hline PO1 & 8 & & & & & & & 1 & $0,706^{* *}$ & 2,484 \\
\hline PO2 & 9 & & & & & & & & 1 & 2,508 \\
\hline$* * p<0.01 ; * p<0.05$ & & & & & & & \\
\hline
\end{tabular}

\section{Discussion and Conclusion}

In the present study, the effect of the degree of internationalization on the exports performance level of the companies was examined. In the study, the degree of internationalization was scrutinized based on human, sales and country dimensions, and it was found that these dimensions had a positive effect on the performance based on second level CFA. Therefore, the $\mathrm{H}_{1}$ hypothesis determined for the study was accepted. There were two main findings of the study. The first was the dimensioning of the degree of internationalization, and the second was the level of impact of DOI on performance. The presence of the relationship between internationalization and performance as suggested in the literature (Chiang and $\mathrm{Yu}$, 2005; Lee et al., 2010) was also demonstrated in the present study.

The DOI factors dimensioned in the study demonstrated a consistency with the country dimension constructed in the study, the market-company correlation decision in the internationalization process (Whitelock, 2002; Chetty and Campell-Hunt, 2003) and conceptualization of market participation (Johanson and Vahlne, 1990). Also, factors such as foreign asset and foreign employee ratios of exports companies based on the company (Dörrenbacher, 2000) coincided with human and sales factors. On the other hand, in the process of internationalization, the physical proximity as well as the cultural proximity factor (Stöttinger and Schlegelmilch, 1998) was influenced by the country diversity (Zahra et al., 2000). Therefore, the necessity of establishing a system that adapts its employees to foreign cultures of operation, at least in terms of foreign language knowledge, as well as an analysis of exports companies based on the country culture could be considered within the human and country factor in this study. Thus, information on cultural distance (Diamantopoulos et al., 2003) could be obtained. 
The three-group conceptualization of the present study could be supported by the assumption of knowledge creation (Brennan and Garvey, 2009) in the context of corporate behavior in the internationalization process model (Forsgren, 2002). If the identified human, sales and country dimensions are considered as a resource for exports or as a predecessor of internationalization, this resource and predecessor could be considered to support the international growth of these companies (Tuppura et al., 2008). The examination of the degree of internationalization in this context also supports the holistic approach of the company to address its import-export activities (Fletcher, 2001). Furthermore, when the degree of internationalization is addressed with the abovementioned three dimensions, it would interact with the elements that has an effect on internationalization success (Ghauri et al., 2003) such as entering the marketplace based on the domain of the industry (Rutashobya and Jaensson, 2004; Smolarski and Wilner, 2005; Jansson and Sandberg, 2008), increasing the performance by becoming an investor in the foreign market (Lu and Beamish, 2001) and transferring the knowledge created into the product as a resource (Jacobs et al., 1997).

Theoretically the most important contribution of the present study is the addition of the speed (country and first) factor to the factors that exist in the literature for DOI measurement to create a general categorization and examination of the effect of the DOI dimensions on the export performances of companies in this context. Based on management practices, the obtained results could serve as a guide for the factors that should be utilized by export companies to increase their export performance, the institutionalization processes that should be improved and to decide where to allocate their resources. In terms of management, assessments can also be conducted based on the three dimensions of the DOI.

The tendency of companies in the internationalization process to increase the ratio of foreign sales (FATA) in total sales and thereby increasing the sum of foreign monetary assets (FSTS) in total monetary assets would significantly affect the sales dimension of DOI. However, foreign market knowledge, foreign language and the trends and attitudes of management and employees about foreign sales and to allocate their assets for internationalization are significant variables. The sales dimension could be easily overcome, especially with executive management's support and determination. However, wars, political, and economic dissociations and naturally the distances between the countries are significant factors with a potential to block companies' foreign sales and allocation of resources.

The second dimension that affects the degree of internationalization of companies is called the country. This sub-dimension includes three sub-factors: the number of countries of export (PDIO), the speed of realizing the first foreign sale (FIRST) and the geographic expansion rate (OSTS). Assessment of these subdimensions would demonstrate that expansion of companies to numerous different countries in foreign sales based on both time and geographical coverage, and high number of offices in foreign countries would increase the degree of internationalization of the company, which would in turn improve the export performance of the company. In fact, when the companies start foreign sales beginning from the year when the company becomes operative, and the company has the tendency to conceive the whole world as an export market and to expand to numerous countries, would also increase the export performances of companies. Indeed, companies that operate in this manner would perceive the world as a market and would benefit from the world market, since they would not only benefit from foreign markets with a limited quantity and quality, but would expand much more. However, for this dimension to be achieved, the attitude and vision of the executive management should be broad and the organization, human and financial resources should be used in this direction. Otherwise, all of this would remain a wish. The categorical data on the participating companies in the present study demonstrated that the ratio of young companies (founded after 2010) was $20 \%$ and the ratio of these companies among the companies that have realized the first exports was $40 \%$, indicating that young companies had started exporting earlier when compared to old companies. As a matter of fact, the fact that the proportion of older companies (companies founded before 1990) in the study was $22 \%$, while only $7 \%$ of those had foreign sales supported the abovementioned finding. In conjunction, these two findings demonstrated that the younger companies initiate foreign sales much sooner than their older counterparts. 
The third dimension that affects the degree of internationalization of companies is called the human dimension. This dimension includes the ratio of foreign branch offices to the total number of offices and the ratio of foreign sales staff to the total number of employees. If companies increase the quantity and quality of foreign sales personnel and the number of new branches in foreign markets in conjunction with other investments, this would not only affect this dimension but also the degree of internationalization of companies positively. As mentioned before, this dimension requires investments in human, financial and technological resources, as well as vision and determination of executive management for development. However, several political, economic, socio-demographic and legal variables would directly affect the establishment of foreign branches. Similarly, the difficulties in employing sufficient number of qualified foreign sales personnel also enhance the significance of the human factor, which is particularly limited in developing countries.

Similar to several studies, there are many limitations in the present study as well. First, the study was conducted without including certain sub-variables such as company size and industry in the analysis. Another limitation is the fact that only objective performance criteria were considered in the present study. Thus, further studies could be conducted with a more extensive sample including companies of different sizes in different industries and the moderator effect of the company size on the analysis of sectoral differences could be investigated. Furthermore, in addition to objective performance criteria, subjective performance criteria could also be included in future studies. Moreover, conducting comparative studies in other developing countries might contribute to the assessment of results from different perspectives.

\section{End Notes}

1. This paper was supported by The Scientific Research Projects Unit of Uludag University as The Small Sized Research Project Numbered KUAP (i)-2014/25 and titled "Analysis of Internationalization Process in Export Companies".

\section{References}

Acs, Z. J., Morck, R., Shaver, J.M. \& Yeung, B. (1997). The internationalization of small and medium-sized enterprises: A policy perspective. Small Business Economics, 9 (1), 7-20.

Altıntaş, M. H. \& Özdemir, E. (2006). inracat işletmelerinin uluslararasılaşması: Türkiye'de faaliyet gösteren KOBi'lere yönelik bir araştırma. Anadolu Üniversitesi Sosyal Bilimler Dergisi, 6(1), 183-204.

Altuntaş, G., Sözüer, A., \& Semerciöz, E. (2015). Uluslararası girişimcilik ile ihracat pazar performansı arasındaki ilişki: Türkiye'deki ihracatçı işletmeler örneği. Doğuş Üniversitesi Dergisi, 16 (1), 65-78.

Andersson, S. (2004). Internationalization in different industrial contexts. Journal of Business Venturing, 19(6), 851-875.

Andersson, S., Gabrielsson, J. \& Wictor, I. (2004). International activities in small firms: examining factors influencing the internationalization and export growth of small firms. Canadian Journal of Administrative Sciences/Revue Canadienne des Sciences de l'Administration, 21(1), 22-34.

Bagozzi, R. P. \& Yi, Y. (2012). Specification, evaluation, and interpretation of structural equation models. Journal of the Academy of Marketing Science, 40(1), 8-34.

Bandeira-de-Mello, R., Fleury, M. T. L., Aveline, C. E. S. \& Gama, M. A. B. (2016). Unpacking the ambidexterity implementation process in the internationalization of emerging market multinationals. Journal of Business Research, 69(6), 2005-2017.

Baursmichmidt, A., Sullivan, D. \& Gillespie, K. (1985). Common factors underlying barriers to export: studies in the US paper industry. Journal of International Business Studies, 16(3), 111-123.

Bausch, A. \& Krist, M. (2007). The effect of context-related moderators on the internationalization-performance relationship: Evidence from meta-analysis. Management International Review, 47(3), 319-347.

Bentler, P. M. (1990). Comparative fit indexes in structural models. Psychological Bulletin, 107(2), 238. 
Blomstermo, A., Eriksson, K. \& Sharma, D. D. (2004). Domestic activity and knowledge development in the internationalization process of firms. Journal of International Entrepreneurship, 2(3), 239-258.

Bobillo, A. M., López-Iturriaga, F. \& Tejerina-Gaite, F. (2012). The effects of international diversification on firm performance: An empirical study across twelve European countries. International Journal of Management, 29(4), 531-542.

Boehe, D. M. \& Jiménez, A. (2016). How does the geographic export diversification-performance relationship vary at different levels of export intensity?. International Business Review, 25(6), 1262-1272.

Bolaji, H. \& Chris, A. (2014). Relationship between internationalisation of firms and economic performance: A case study selected banks in Nigeria. Journal of Economics and Sustainable Development, 5(5), 160-166.

Boter, H. \& Holmquist, C. (1996). Industry characteristics and internationalization processes in small firms. Journal of Business Venturing, 11(6), 471-487.

Brennan, L. \& Garvey, D. (2009). The role of knowledge in internationalization. Research in International Business and Finance, 23(2), 120-133.

Cadogan, J. W., Paul, N. J., Salminen, R. T., Puumalainen, K., \& Sundqvist, S. (2001). Key antecedents to "export" marketoriented behaviors: a cross-national empirical examination. International Journal of Research in Marketing, 18(3), 261-282.

Canıtez, M. \& Yeniçeri, T. (2007), Ihracat performansı düşük olan KOBi'ler ile yüksek olan KOBi'lerin farklılıklarını belirlemeye yönelik bir pilot araştırma, Erciyes Üniversitesi Iktisadi ve Idari Bilimler Fakültesi Dergisi, 29, 113-134.

Capar, N. \& Kotabe, M. (2003). The relationship between international diversification and performance in service firms. Journal of International Business Studies, 34(4), 345-355.

Carneiro, J., da Silva, J. F. \& da Rocha, A. (2011b). Strategic profiles of Brazilian exporters and performance implications. Journal of Business Research, 64(3), 250-257.

Carneiro, J., Rocha, A. D. \& Silva, J. F. D. (2011a). Determinants of export performance: a study of large Brazilian manufacturing firms. BAR-Brazilian Administration Review, 8(2), 107-132.

Cavusgil, S. T. \& Nevin, J. R. (1981). Internal determinants of export marketing behavior: An empirical investigation. Journal of Marketing Research, XVII( February), 114-119.

Cavusgil, S. T. (1980). On the internationalization process of firms. European Research, 8(6), 273-281.

Chang, J. (2007). International expansion path, speed, product diversification and performance among emerging-market MNEs: evidence from Asia-Pacific multinational companies. Asian Business \& Management, 6(4), 331-353.

Chen, S. \& Tan, H. (2012). Region effects in the internationalization-performance relationship in Chinese firms. Journal of World Business, 47(1), 73-80.

Chetty, S. \& Campbell-Hunt, C. (2003). Paths to internationalisation among small-to medium-sized firms: a global versus regional approach. European Journal of Marketing, 37(5/6), 796-820.

Chetty, S. \& Holm, D. B. (2000). Internationalisation of small to medium-sized manufacturing firms: a network approach. International Business Review, 9(1), 77-93.

Chetty, S., Johanson, M. \& Martín, O. M. (2014). Speed of internationalization: conceptualization, measurement and validation. Journal of World Business, 49(4), 633-650.

Chiang, Y. C. \& Yu, T. H. (2005). The relationship between multinationality and the performance of Taiwan firms. Journal of American Academy of Business, 6(1), 130-134.

Contractor, F. J. (2007). Is international business good for companies? The evolutionary or multi-stage theory of internationalization vs. the transaction cost perspective. Management International Review, 47(3), 453-475.

Contractor, F. J., Kundu, S. K. \& Hsu, C. C. (2003). A three-stage theory of international expansion: The link between multinationality and performance in the service sector. Journal of International Business Studies, 34(1), 5-18.

Conway, T. \& Swift, J. S. (2000). International relationship marketing - The importance of psychic distance. European Journal of Marketing, 34(11/12), 1391-1414.

Danışman, A., \& Sökmen, A. G. (2007). Girişimci özellikleri ve firma niteliklerinin ihracat performansına etkisi: KOBi’ler üzerinde bir araştrrma. Çukurova Üniversitesi Sosyal Bilimler Enstitüsü Dergisi, 16(1), 213-230.

De Clercq, D., Sapienza H.J. \& Crijns, H. (2005). The internationalization of small and medium-sized firms. Small Business Economics 24, 409-419. 
Dean, D. L., Mengüç, B. \& Myers, C. P. (2000). Revisiting firm characteristics, strategy, and export performance relationship: a survey of the literature and an investigation of New Zealand small manufacturing firms. Industrial Marketing Management, 29(5), 461-477.

Dhanaraj, C. \& Beamish, P. W. (2003). A resource-based approach to the study of export performance. Journal of Small Business Management, 41(3), 242-261.

Diamantopoulos, A. \& Siguaw, J. A. (2006). Formative versus reflective indicators in organizational measure development: A comparison and empirical illustration. British Journal of Management, 17(4), 263-282.

Diamantopoulos, A., Schlegelmilch, B. B. \& Allpress, C. (1990). Export marketing research in practice: a comparison of users and non-users. Journal of Marketing Management, 6(3), 257-273.

Diamantopoulos, A., Souchon, A. L., Durden, G. R., Axinn, C. N. \& Holzmüller, H. H. (2003). Towards an understanding of cross-national similarities and differences in export information utilization: A perceptual mapping approach. International Marketing Review, 20(1), 17-43.

Dörrenbächer, C. (2000). Measuring corporate internationalisation. Intereconomics, 35(3), 119-126.

Elango, B. \& Sethi, S. P. (2007). An exploration of the relationship between country of origin (COE) and the internationalization - performance paradigm. Management International Review, 47(3), 369-392.

Erdil, T. S. (2012). An analysis of internationalisation behavior of firms through activities and the case of Turkish firms. Procedia-Social and Behavioral Sciences, 58, 1247-1255.

Erkutlu, H. \& Eryiğit, S. (2001). Uluslararasılaşma süreci. Gazi Üniversitesi Iktisadi ve Idari Bilimler Fakültesi Dergisi, 3(3), 149-164.

Evans, J., Treadgold, A. \& Mavondo, F. (2000). Explaining export development through psychic distance. International Marketing Review, 17(2), 164-169.

Fillis, I. (2001). Small firm internationalisation: an investigative survey and future research directions. Journal of Management Decision, 39(9), 767-783.

Fletcher, R. (2001). A holistic approach to internationalisation. International Business Review, 10(1), 25-49.

Forsgren, M. (2002). The concept of learning in the Uppsala internationalization process model: a critical review. International Business Review, 11(3), 257-277.

Ganotakis, P. \& Love, J. H. (2012). Export propensity, export intensity and firm performance: The role of the entrepreneurial founding team. Journal of International Business Studies, 43(8), 693-718.

Ghauri, P., Lutz, C. \& Tesfom, G. (2003). Using networks to solve export-marketing problems of small-and medium-sized firms from developing countries. European Journal of Marketing, 37(5/6), 728-752.

Greve, P., Nielsen, S. \& Ruigrok, W. (2009). Transcending borders with international top management teams: A study of European financial multinational corporations. European Management Journal, 27(3), 213-224.

Gripsrud, G. (1990). The determinants of export decisions and attitudes to a distant market: Norwegian fishery exports to Japan. Journal of International Business Studies, 21(3), 469-485.

Gubik, A.S. \& Bartha, Z. (2014). SME Internalisation Index (SMINI) Based on the Sample of the Visegrad Countries (chapter 2). In: Gubik, A.S. \& Wach, K. (eds), International Entrepreneurship and Corporate Growth in Visegrad Countries. Mickolc: University of Miskolc, 23-40.

Hair, J. F., Ringle, C. M. \& Sarstedt, M. (2011). PLS-SEM: Indeed a silver bullet. Journal of Marketing theory and Practice, $19(2), 139-152$.

Hassel, A., Höpner, M., Kurdelbusch, A., Rehder, B. \& Zugehör, R. (2003). Two dimensions of the internationalization of firms. Journal of Management Studies, 40(3), 705-723.

He, X., Lin, Z. \& Wei, Y. (2016). International market selection and export performance: A transaction cost analysis. European Journal of Marketing, 50(5/6), 916-941.

Hitt, M. A., Li, D. \& Xu, K. (2016). International strategy: From local to global and beyond. Journal of World Business, 51(1), 58-73.

Hsu, C. C. \& Pereira, A. (2008). Internationalization and performance: The moderating effects of organizational learning. Omega, 36(2), 188-205.

letto-Gillies, G. (1998). Different conceptual frameworks for the assessment of the degree of internationalization: an empirical analysis of various indices for the top 100 transnational corporations. Transnational Corporations, 7(1), 17-40. 
Jacobs, L. W., Wills, J. R., Coskun Samli, A. \& Bullard, W. R. (1997). Internationalization of domestic product life cycles: An exploration of causality. International Marketing Review, 14(1), 75-87.

Jansson, H. \& Sandberg, S. (2008). Internationalization of small and medium sized enterprises in the Baltic Sea Region. Journal of International Management, 14(1), 65-77.

Javalgi, R. R. G., Griffith, D. A. \& Steven White, D. (2003). An empirical examination of factors influencing the internationalization of service firms. Journal of Services Marketing, 17(2), 185-201.

Johanson, J., \& Vahlne, J. E. (1990). The mechanism of internationalisation. International Marketing Review, 7(4), $11-24$.

Jones, M. V. (2001). First steps in internationalisation: Concepts and evidence from a sample of small high-technology firms. Journal of International Management, 7(3), 191-210.

Karagozoglu, N., \& Lindell, M. (1998). Internationalization of small and medium - sized technology - based firms: An exploratory study. Journal of Small Business Management, 36 (1), 44 - 59.

Kayabaşı, A., Kiracı, H., Kanberoğlu, Z., \& Oğuz, A. (2010). KOBi’lerde ihracat performansını belirleyen unsurların incelenmesi: İnegöl'de faaliyette bulunan işletmeler üzerinde bir alan araştırması. Dumlupınar Üniversitesi Sosyal Bilimler Dergisi, (28), 1-12.

Kennelly, J. J. \& Lewis, E. E. (2001). Degree of internationalization and corporate environmental performance: is there a link?. In Proceedings of the International Association for Business and Society, 12, 317-328.

Kling, G. \& Weitzel, U. (2011). The internationalization of Chinese companies: firm characteristics, industry effects and corporate governance. Research in International Business and Finance, 25(3), 357-372.

Knudsen, T. \& Madsen, T. K. (2002). Export strategy: a dynamic capabilities perspective. Scandinavian Journal of Management, 18(4), 475-502.

Korkmaz, S., Ermeç, A., \& Yücedağ, N. (2009). İşletmelerin yenilikçi kabiliyetleri ve ihracat performanslarına etkileri. Anadolu Üniversitesi Sosyal Bilimler Dergisi, 9(2), 83-104.

Kurt, i., \& Bilge, H. (2016). The link between international entrepreneurship and export performance: Example of Manisa Uluslararası girişimcilik ve ihracat performansı ilişkisi: Manisa örneği. Journal of Human Sciences, 13(3), 46854696.

Lages, C., Lages, C. R. \& Lages, L. F. (2005). The RELQUAL scale: a measure of relationship quality in export market ventures. Journal of Business Research, 58(8), 1040-1048.

Lages, L.F. \& Lages, C.R. (2004). The STEP scale: a measure of short-term export performance improvement. Journal of International Marketing, 12(1), 36-56.

Lee, J.R. \& Chen, J. S. (2003). Internationalization, local adaptation, and subsidiary's entrepreneurship: An exploratory study on Taiwanese manufacturing firms in Indonesia and Malaysia. Asia Pacific Journal of Management, 20(1), 51-72.

Lee, M. \& Ali, A. (2001). The Impact of firm size and international experience on export behavior. In Proceedings of Taipei 46th ICSB World Conference. http://www.sbaer.uca.edu/Research/ 2001/ICSB/E-6-4.pdf (Erişim Tarihi, 14 Şubat 2017)

Lee, T., Chan, K.C., Yeh, J.H. \& Chan, H.Y. (2010). The impact of internationalization on firm performance: A quantile regression analysis. International Review of Accounting, Banking and Finance, 2(4), 39-59.

Leonidou, L. C. (1997). Finding the right information mix for the export manager. Long Range Planning, 30(4), 572-584.

Leonidou, L.C. \& Theodosiou, M. (2004). The export marketing information system: an integration of the extant knowledge. Journal of World Business, 39(1), 12-36.

Leonidou, L.C. (2000). Barriers to export management: an organizational and internationalization analysis. Journal of International Management, 6(2), 121-148.

Lim, J. S., Sharkey, T. W. \& Kim, K. I. (1991). An empirical test of an export adoption model. MIR: Management International Review, 31(1), 51-62.

Loane, S., Bell, J. D. \& McNaughton, R. (2007). A cross-national study on the impact of management teams on the rapid internationalization of small firms. Journal of World Business, 42(4), 489-504.

Loncan, T. \& Nique, W. M. (2010). Degree of internationalization and performance: evidence from emerging Brazilian multinational firms. GCG Georgetown University - Universia, 4(1), 40-51.

López-Morales, J. S. \& Gómez-Casas, M. M. (2014). Degree of internationalization (DOI) and performance relationship: an empirical and conceptual approach. International Journal of Academic Research in Business and Social Sciences, 4(9), 39-56. 
Lu, J. W. \& Beamish, P. W. (2001). The internationalization and performance of SMEs. Strategic Management Journal, 22(6-7), 565-586.

Lu, J. W. \& Beamish, P. W. (2004). International diversification and firm performance: The S-curve hypothesis. Academy of Management Journal, 47(4), 598-609.

Luo, Y., Hongxin Zhao, J. \& Du, J. (2005). The internationalization speed of e-commerce companies: an empirical analysis. International Marketing Review, 22(6), 693-709.

Martineau, C. \& Pastoriza, D. (2016). International involvement of established SMEs: A systematic review of antecedents, outcomes and moderators. International Business Review, 25(2), 458-470.

Moen, $\varnothing$. \& Servais, P. (2002). Born global or gradual global? Examining the export behavior of small and medium-sized enterprises. Journal of International Marketing, 10(3), 49-72.

Morgan, R. E. \& Katsikeas, C. S. (1998). Exporting problems of industrial manufacturers. Industrial Marketing Management, 27(2), 161-176.

Naik, S.S. \& Reddy Y.V. (2013). Structuring the prediction model of export performance of selected Indian industries: A comparative analysis. Open Access Scientific Reports 2(3), 1-7.

Nehrt, C. (1999). Degree of foreign sales and foreign assets as joint indicators of firm performance. In ABAS International Conference, Barcelona, Spain, 1-30.

Nielsen, S. (2010). Top management team internationalization and firm performance. Management International Review, 50(2), 185-206.

Ogasavara, M. H., Boehe, D. M., \& Barin Cruz, L. (2016). Experience, resources and export market performance: The pivotal role of international business network ties. International Marketing Review, 33(6), 867-893.

O'Grady, S. \& Lane, H. W. (1996). The psychic distance paradox. Journal of International Business Studies, 27(2), 309333.

Onkelinx, J., Manolova, T. S. \& Edelman, L. F. (2016). The human factor: Investments in employee human capital, productivity, and SME internationalization. Journal of International Management, 22(4), 351-364.

Pan, W. H. \& Chao, Y. S. (2010). The joint effects of geographical diversification to MNEs' performance through China investment. Journal of Global Business Management, 6(1), 1-13.

Pangarkar, N. (2008). Internationalization and performance of small-and medium-sized enterprises. Journal of World Business, 43(4), 475-485.

Papadopoulos, N. \& Martín, O. M. (2010). Toward a model of the relationship between internationalization and export performance. International Business Review, 19(4), 388-406.

Perçin, S. (2005). ìhracat performansını etkileyen faktörlerin belirlenmesi ve firmaların ihracat performans ölçülerine göre sınıflandırılmasındaki rolü: iso 1000 sanayi firmaları uygulaması. Kocaeli Üniversitesi Sosyal Bilimler Enstitüsü Dergisi, 9, 139-155.

Pinho, J. C. \& Martins, L. (2010). Exporting barriers: insights from Portuguese small-and medium-sized exporters and non-exporters. Journal of International Entrepreneurship, 8(3), 254-272.

Prange, C. \& Verdier, S. (2011). Dynamic capabilities, internationalization processes and performance. Journal of World Business, 46(1), 126-133.

Ramaswamy, K., Kroeck, K. G. \& Renforth, W. (1996). Measuring the degree of internationalization of a firm: A comment. Journal of International Business Studies, 27(1), 167-177.

Reid, S. (1983). Firm internationalization, transaction costs and strategic choice. International Marketing Review, 1(2), 44-56.

Riahi-Belkaoui, A. (1998). The effects of the degree of internationalization on firm performance. International Business Review, 7(3), 315-321.

Rigdon, E. E. (1996). CFI versus RMSEA: A comparison of two fit indexes for structural equation modeling. Structural Equation Modeling: A Multidisciplinary Journal, 3(4), 369-379.

Ruigrok, W., Amann, W. \& Wagner, H. (2007). The internationalization-performance relationship at Swiss firms: A test of the S-shape and extreme degrees of internationalization. Management International Review, 47(3), 349-368.

Rundh, B. (2001). International market development: new patterns in SMEs international market behaviour?. Marketing Intelligence \& Planning, 19(5), 319-329.

Rutashobya, L. \& Jaensson, J. E. (2004). Small firms' internationalization for development in Tanzania: Exploring the network phenomenon. International Journal of social economics, 31(1/2), 159-172. 
Ruzzier, M., AntonciC, B., Hisrich, R. D. \& Konecnik, M. (2007). Human capital and SME internationalization: A structural equation modeling study. Canadian Journal of Administrative Sciences, 24(1), 15-29.

Schermelleh-Engel, K., Moosbrugger, H. \& Müller, H. (2003). Evaluating the fit of structural equation models: Tests of significance and descriptive goodness-of-fit measures. Methods of Psychological Research Online, 8(2), 23-74.

Singla, C. \& George, R. (2013). Internationalization and performance: A contextual analysis of Indian firms. Journal of Business Research, 66(12), 2500-2506.

Smolarski, J. M. \& Wilner, N. (2005). Internationalisation of SMEs: a micro-economic approach. Journal of Business Chemistry, 2(2), 55-70.

Solberg, C., Kristiansen, B. \& Slattebrekk, L. (2002). Internationalisation strategies and globalisation. In A test of the nine strategies windows framework among Norwegian exporting firms, paper presented at the EIBA conference, Athens, December, (http://www.aueb.gr/deos/EIBA2002.files/PAPERS/C112.pdf)

Stöttinger, B. \& Schlegelmilch, B. B. (1998). Explaining export development through psychic distance: enlightening or elusive?. International Marketing Review, 15(5), 357-372.

Suárez-Ortega, S. M. \& Álamo-Vera, F. R. (2005). SMES' internationalization: firms and managerial factors. International Journal of Entrepreneurial Behavior \& Research, 11(4), 258-279.

Sullivan, D. \& Bauerschmidt, A. (1988). Common factors underlying incentive to export: studies in the European forest products industry. European Journal of Marketing, 22(10), 41-55.

Sullivan, D. (1994). Measuring the degree of internationalization of a firm. Journal of International Business Studies, 25(2), 325-342.

Sürer, A., \& Mutlu, H.M. (2012). Pazar, e-pazarlama, girişimcilik ve teknoloji yönelimlerinin ihracat performansı üzerine etkileri. Journal of Internet Applications \& Management/Internet Uygulamaları ve Yönetimi Dergisi, 3(2), 27-52.

Tallman, S. \& Li, J. (1996). Effects of international diversity and product diversity on the performance of multinational firms. Academy of Management Journal, 39(1), 179-196.

Tan, H. \& Mathews, J. A. (2015). Accelerated internationalization and resource leverage strategizing: The case of Chinese wind turbine manufacturers. Journal of World Business, 50(3), 417-427.

Thomas M. J. \& Araujo, L. (1985). Theories of export behaviour: a critical analysis. European Journal of Marketing, 19(2), 42-52.

Thomas, D. E. \& Eden, L. (2004). What is the shape of the multinationality-performance relationship?. Multinational Business Review, 12(1), 89-110.

Torlak, Ö., Kula, V., \& Özdemir, Ş. (2007). Türk işletmelerinin ihracat performansı belirleyicileri. iktisadi ve Idari Bilimler Fakültesi Dergisi, 9(1), 1-12.

Tuppura, A., Saarenketo, S., Puumalainen, K., Jantunen, A. \& Kyläheiko, K. (2008). Linking knowledge, entry timing and internationalization strategy. International Business Review, 17(4), 473-487.

UNCTAD (1998). World Investment Report 1998. Trends and Determinants. New York, Geneva: United Nations.

Vardar, N. (2016). Turkish EMNCs with foreign direct investments in the EU. (Chapter 7) In: Louis Brennan and Caner Bakir (Eds), Emerging Market Multinationals in Europe, Routledge, New York, 95-112.

Wang, C. H., Hsu, L. C. and Fang, S. R. (2008). The determinants of internationalization: Evidence from the Taiwan high technology industry. Technological Forecasting and Social Change, 75(9), 1388-1395.

Welch, C., Nummela, N. and Liesch, P. (2016). The Internationalization process model revisited: An agenda for future research. Management International Review, 56(6), 783-804.

Westhead, P., Binks, M., Ucbasaran, D. and Wright, M. (2002). Internationalization of SMEs: A research note. Journal of Small Business and Enterprise Development, 9(1), 38-48.

Whitelock, J. (2002). Theories of internationalization and their impact on market entry. International Marketing Review, 19(4), 342-347.

Wickramasekera, R. and Oczkowski, E. (2004). Key determinants of the stage of internationalization of Australian wineries. Asia Pacific Journal of Management, 21(4), 425-444.

Wood, V. R. and Robertson, K. R. (2000). Evaluating international markets: The importance of information by industry, by country of destination, and by type of export transaction. International Marketing Review, 17(1), 34-55.

Yip, G. S., Biscarri, J. G. and Monti, J. A. (2000). The role of the internationalization process in the performance of newly internationalizing firms. Journal of International Marketing, 8(3), 10-35. 
Yuan, K. H., Chan, W., Marcoulides, G. A. and Bentler, P. M. (2016). Assessing structural equation models by equivalence testing with adjusted fit indexes. Structural Equation Modeling: A Multidisciplinary Journal, 23(3), 319-330.

Zahra, S. A., Ireland, R. D. and Hitt, M. A. (2000). International expansion by new venture firms: International diversity, mode of market entry, technological learning, and performance. Academy of Management Journal, 43(5), 925950.

Zhang, Y. and Toppinen, A. (2011). Internationalization and financial performance in the global forest industry. International Forestry Review, 13(1), 96-105. 